\title{
Reconsideración de la poesía cervantina: los defectos métricos y estilísticos de Cervantes
}

\author{
Rodrigo Olay VAldÉS*
}

\section{PLANTEAMIENTO}

Ha venido siendo una firme convicción crítica considerar a Cervantes como un poeta mediocre y poco dotado técnicamente. En esta línea, Ricardo Rojas (1916), Francisco Rodríguez Marín (1935) y Gerardo Diego (1948) se han referido al oído torpe de Cervantes, a la poca dulzura de su versificación y, en definitiva, a sus limitaciones métricas, todo lo cual supone una severa impugnación de las dotes poéticas de don Miguel. Por mucho que en tiempos recientes la crítica haya emprendido una revaloración sistemática de la poesía cervantina, muchas veces poniendo de relieve su heterodoxia y destacando su posible componente dialógico, nadie se ha parado aún a intentar desmentir a Diego, Rojas y Rodríguez Marín aplicando sus propias armas estilísticas: apenas se ha vuelto a examinar la acentuación cervantina, ni su empleo de la sinalefa, por poner dos claros ejemplos. Se trata de una asignatura pendiente de la crítica cervantina, una empresa aún sin acometer que hemos creído oportuno revisar, a la vista de que muchos de los supuestos errores técnicos que tradicionalmente se han imputado a Cervantes no nos han parecido tales las más de las veces. Es hora de reconsiderar la inercia que ha llevado a ver en Cervantes un torpe versificador.

\footnotetext{
${ }^{*}$ Universidad de Oviedo.
} 


\section{MOTIVOS PARA EL DESCONCIERTO}

La poesía de Cervantes siempre ha sido considerada la hermana pobre de los estudios literarios cervantinos: carecemos todavía de una edición completa, rigurosa, moderna y exhaustiva de sus versos (el encomiable trabajo de Ricardo Rojas es ya de 1916; actualmente solo contamos con la meritoria pero incompleta edición de Gaos, a quien la muerte sorprendió cuando preparaba el último de los tres tomos en que había proyectado la edición de las poesías de Cervantes, de la que solo llegaron a ver la luz los dos primeros; con todo, un equipo coordinado por José Montero Reguera (Montero Reguera y otros, en prensa) trabaja en la actualidad en una ambiciosa y exhaustiva edición pormenorizada anotada de la poesía completa de Cervantes); carecemos también de un estudio de conjunto sobre su poesía. Determinados críticos han ido sumando diversas publicaciones breves sobre el tema hasta formar un corpus nada desdeñable (es el caso de los acertados esfuerzos de Francisco Javier Díez de Revenga, Carlos Mata Induráin, Pedro Ruiz Pérez, Fernando Romo Feito y, especialmente, José Montero Reguera, acaso el mayor especialista en la materia, sin olvidar nunca a Elías L. Rivers), pero aún nos falta un trabajo totalizador y liberado de los clichés que han venido repitiéndose incansablemente en el marco de la bibliografía sobre la poesía de Cervantes.

Un lector que se acerque a lo que el cervantismo ha producido sobre la poesía del autor del Quijote se encontrará con varias sorpresas: la convivencia de opiniones enfrentadas y contradictorias es completamente normal a cualquier nivel de análisis. Podemos leer, por ejemplo, que si Mayans considera que las «composiciones de arte mayor [de Cervantes] son inferiores [a las de arte menor]», Cotarelo y Valledor, por su parte, aprecia que «para el empleo de los metros largos Cervantes fue más diestro»; si Mor de Fuentes ve la Numancia «pueril en el lenguaje», Gil y Zárate encuentra «rasgos admirables y trozos notables de versificación», etc. (Rojas, 1916: XLVIII). Ante este tipo de grandes obras, la proliferación de bibliografía se convierte a veces en una ruidosa capa de niebla que estorba a la vista la lectura del texto. En el marco de la crítica de la poesía cervantina, se han dedicado más páginas a repetir que Cervantes no ha gozado de prestigio como poeta que a intentar explicar por qué, y ya no digamos que a intentar desmentir semejante juicio. Y así, a fuerza de repetido, ha acabado siendo cierto que Cervantes es un poeta mediocre o incluso malo, y como tal lo tratan los manuales y los epítetos ${ }^{1}$.

Si acudimos a uno de los textos clásicos e insoslayables sobre la materia, el enjundioso «Cervantes y la poesía» de Gerardo Diego (1948: 215), nos encontramos con que se le coloca a la altura estética de otro poeta complutense, «Francisco de Figeroa», y a nadie se le ocurriría tildar de mediocre, y ya no

1. De obligada referencia en este punto es el último status quaestionis dedicado a la poesía de Cervantes, publicado por el profesor José Montero Reguera (2011); se trata de un texto cumplidísimo en el que puede encontrarse la mejor y más completa bibliografía existente acerca del tema que nos ocupa. 
digamos de malo, a Figueroa, toda vez que son estos adjetivos no infrecuentemente aplicados a Cervantes. ¿De dónde viene, en fin, la inercia crítica responsable de la pobre consideración de la poesía cervantina? En nuestra opinión, de tres motivos esencialmente: primero, de la comparación con la prosa de Cervantes; segundo, de las apreciaciones que Cervantes hizo sobre su propia poesía; tercero, de lo poquísimo que se ha leído la poesía de Cervantes, de quien un lector culto, dejando al margen los poemas insertos en el Quijote, no conocerá más que el famoso «Soneto al túmulo de Felipe II en Sevilla».

Poco podemos hacer por glosar la primera de las razones que aducimos. Es evidente que Cervantes alcanzó en prosa una excelencia hoy universalmente reconocida que no merecen sus versos; pero, en palabras de Menéndez Pelayo (1941: 259), que Cervantes sea el primero de nuestros prosistas no lo hace el último de nuestros poetas. De hecho, como asevera Gaos (1974: 24), la poesía de Cervantes es plenamente «suya», en ella se reconocen sus temas y motivos fundamentales, y, por lo tanto, es, si acaso, todo lo mala que puede ser siendo de Cervantes.

Más miga tiene el segundo motivo. Aquí y allá, usualmente en sus siempre jugosos textos prologales, alude Cervantes a su fortuna como poeta. Se hace irrenunciable aducir el terceto en que cualquier estudioso estará pensando, cuya lectura literal tanto daño ha hecho a Cervantes: "Yo que siempre me afano y me desvelo / por parecer que tengo de poeta / la gracia que no quiso darme el cielo» (Viaje del Parnaso, I, vv. 25-27). Para muchos de nuestros eruditos, el Viaje del Parnaso parece reducirse a esos tres versos, y eso que no han faltado críticos, particularmente Gaos (1974, vol. I: 11), que indicasen al menos media docena de pasajes del Viaje en los que Cervantes se muestra orgulloso de sus dotes poéticas y de su obra en verso (pueden revisarse, entre otros, versos y pasajes tales como I, v. 202, vv. 223-228, v. 291; II, vv. 8893, v. 396; IV, vv. 28-68; o VIII, v. 97-98; y, en especial, IV, vv. 338-342). Lamentablemente, para llegar a leer estos fragmentitos era necesario pasar más adelante del verso veinticinco del Viaje, y, aunque parezca esto una perogrullada, tenemos para nosotros que si Cervantes hubiera colocado lo de la gracia que no quiso darle el cielo en el canto sexto en lugar de en la primera página de su libro, no serían necesarias explicaciones como esta.

No han faltado tampoco críticos que agudamente pusiesen de relieve el contexto irónico en el que se enmarca el ya citado terceto, que no es más que un ejemplo paradigmático del tópico conocido como «humilitas», enmarcado en la preceptiva captatio benevolentiae con que se abre el Viaje. Además, no nos faltan testimonios de la estima en que Cervantes tenía sus propios versos: además de los ya citados del Viaje del Parnaso, conviene, por ejemplo, atender a las muchas veces que, tras insertar un poema en alguna de sus novelas, o bien el narrador o alguno de los personajes comentan «lo bien que pareció» la composición leída ${ }^{2}$. 
La última de las razones antes aludidas que explican el arrumbamiento crítico del Cervantes poeta es, sencillamente, que se le ha leído muy poco. Y, como se le ha leído poco, nadie o casi nadie ha intentado revalorizarlo: es la pescadilla que se muerde la cola. De hecho, no solo es que no se le haya leído, es que a veces tampoco se le ha podido leer: desde la edición de Rojas de 1916 y hasta dos antologías publicadas con motivo del IV centenario de la primera parte Quijote, la de José Manuel Caballero Bonald (2005), y la de Alberto Blecua y Antonio Pérez Lasheras (2005), estaba completamente fuera de circulación cualquier compilación que recogiese los poemas que Cervantes intercaló en su teatro, y que casi unánimemente son considerados lo mejor que escribiera en verso. Hoy podemos dar por remediado este problema. Cervantes es autor de poemas absolutamente memorables en muy diversos géneros y tonos: sonetos amorosos y burlescos, romances, canciones, letrillas y seguidillas; cultivó formas tan alambicadas y exigentes como los versos de cabo roto y escribió una sextina (forma muy infrecuente en nuestra tradición) que un gustador de poesía tan fino como Jaime Gil de Biedma (2010: 1077) no dudó en tildar de «muy hermosa», a lo que acaso haya que añadir aquella famosa cita de Martín de Riquer que quiere que «en el cultivo de la sextina sólo puede salir airoso un gran poeta» (Apud Domínguez Caparrós, 2000: 225). Cervantes, además, resucitó para siempre el ovillejo, composición solo a la altura de diestros versificadores. Bastan estas breves notas y basta, en definitiva, leer a Cervantes para poner en cuarentena tanto melindre como se le ha afeado.

\section{CERVANTES: UNA IMAGEN DISTORSIONADA}

En este fuego cruzado, la imagen de Cervantes se nos representa como un enigma. Antes apuntamos que una de las razones del poco prestigio de la poesía de Cervantes es que sigue siendo la gran desconocida de su producción. Y no nos referimos ya a que falte un adecuado trabajo de depuración textual de sus obras en verso (cuántos errores nuestros le estaremos atribuyendo), sino a que en el pensamiento crítico siguen pesando excesivamente las etiquetas genéricas: es difícil que quien ha destacado en determinado género literario merezca la atención de los estudiosos por su faceta creadora en un género diferente.

Que la crítica haya insistido especialmente en los defectos métricos y estilísticos de Cervantes (defectos que, como demuestra Ricardo Rojas (1916:

Anselmo», «También alabó este segundo soneto Anselmo»; I, 40: «No parecieron mal los sonetos»; o II, 18: «En acabando de decir su glosa don Lorenzo, se levantó en pie don Quijote, y en voz levantada, que parecía grito, asiendo con su mano la derecha de don Lorenzo dijo: -iViven los cielos donde más altos están, mancebo generoso, que sois el mejor poeta del orbe [...]», «-¡Bendito sea Dios -dijo don Quijote habiendo oído el soneto de don Lorenzo-, que entre los infinitos poetas consumidos que hay he visto un consumado poeta». Citamos siempre por Rico (dir.) (2004). 
LV), tienen una incidencia porcentual muy pequeña) o que nos falte un estudio pormenorizado de su poesía son síntomas claros del peso que sigue teniendo la figuración decimonónica de Cervantes como «ingenio lego» a la hora de atender los versos del complutense: al fin y al cabo, no hemos llegado hasta el fondo en el estudio de las fuentes de Cervantes, ni en el análisis de sus peculiaridades estilísticas, ni se ha conseguido ofrecer una edición fiable de sus versos; en definitiva, se ha insistido excesivamente en la misma pregunta (¿era Cervantes poeta?) para dar casi siempre parecida respuesta. Consecuencia de la conceptuación del Cervantes poeta como «ingenio lego» es la condescendencia y la superioridad con la que se la ha venido contemplado. Baste como muestra un ejemplo: en su por otra parte utilísima edición de las poesías cervantinas, Gaos no deja escapar sin consignar en nota al pie todo verso hipermétrico que encuentra, dando indirectamente por hecho que el error es de Cervantes (Gaos (ed.), 1981, II: 66, 106, 128, 148, 226). Si nos preguntásemos cuántos editores tratarían así a Garcilaso, Góngora o Quevedo, acaso nos daríamos cuenta hasta qué punto ha sido desprestigiada la imagen del Cervantes poeta.

En los últimos años, sin embargo, y de forma no poco paradójica, se ha empezado a leer la poesía de Cervantes desde ciertos presupuestos más o menos comunes a la crítica del Cervantes prosista o, más exactamente, a la crítica del Quijote. Y decimos que «paradójica» porque todas estas perspectivas críticas recientes parten de una apreciación de Clemencín, el más inclemente de los cervantistas con los versos de don Miguel. Apunta Clemencín, al referirse a las composiciones que cierran la primera parte del Quijote, atribuidas a los Académicos de Argamasilla (I, LII), que «Cervantes hubo de hacer oscuras y malas de propósito las presentes composiciones, para ridiculizar así a los académicos que suponían ser sus autores» (1833-1839: vol. III: 536). La idea, entonces, es que, en ciertos poemas, Cervantes busca que sus versos se adecuen a la psicología de quien los enuncia; no pueden, por tanto, ser juzgados fuera de su contexto ni como versos «de Cervantes», y no serían, en puridad, poesía lírica: su mérito, más bien dramático, se hallaría principalmente en la sutil representación del sentimiento y el modo de ser del personaje que enuncia los versos y al que los versos representan. No debemos hacer mucho esfuerzo para entender este procedimiento, porque es fundamentalmente el que explica el funcionamiento y el mérito del «Soneto al túmulo de Felipe II en Sevilla» según se ha venido explicando desde siempre (Ayala, 1971: 718-730)³ ${ }^{3}$ En dicho soneto, la grandilocuencia y la vaciedad de la lengua empleada en los cuartetos no es un defecto de Cervantes, sino, antes bien, un formidable hallazgo, en tanto que define sutil e indirectamente a quien así habla. Aplicando este procedimiento, se ha llamado repetidamente la atención sobre el hecho de que la poesía de Cervantes nunca aparece autónomamente (Cervantes nunca

3. Puede consultarse también la edición crítica y el análisis de este soneto propuesto en Solís de los Santos (2004). 
publicó un libro de versos, excepción hecha del Viaje del Parnaso, un largo poema narrativo y burlesco), sino intercalada en su prosa y puesta en labios de un personaje que se expresa mediante los versos.

Luis Cernuda fue un paso más allá de Clemencín en un famoso artículo, «Cervantes, poeta» (1962), que sin duda define mejor al propio Cernuda que al autor objeto de su estudio. En este texto, consciente o inconscientemente, Cernuda, poco antes de morir ( $† 1963)$, se identifica con Cervantes: destaca la antipatía que sus contemporáneos le tuvieron (como Cernuda sentía que le tenían a él), singulariza a Cervantes anacrónicamente como poeta meditativo (como él mismo lo era) y subraya el peso del tema de España en los versos del autor del Quijote, descontextualizando, de forma ingeniosa pero insostenible filológicamente, un famoso pasaje de la Numancia en el que encuentra «una visión profética» que relaciona explícitamente con la Guerra Civil (Cernuda, 2006: 695-697). Finaliza dicho artículo con una idea que nos importa mucho copiar:

El soneto del que tan ufano estaba Cervantes nos habla de otra cualidad suya: lo que en él se destaca no es tanto la retórica de la composición, sino su humanidad, la realidad ahí encerrada de una persona a quien el poeta da voz: el valentón que se declara al fin del soneto. Cosa sintomática en el novelista que Cervantes era fundamentalmente, y nos hace ver, oír, percibir la presencia de un ser humano. Cualidad propia, a su manera de novelista, de lo que en la poesía moderna equivale al monólogo dramático de Browning, tipo de poesía este que tiene una descendencia larga e ilustre [...]. Algo incipiente de dicha forma aparece ya en Cervantes (Cernuda, 2006: 701).

Esta apreciación gozará de una importancia capital y determinará en gran medida el análisis que hoy parece estar asentándose en torno a la poesía de Cervantes. De hecho, esta misma línea interpretativa, perfectamente plausible, es defendida en la actualidad, en parecidos términos a los de Cernuda, por Jenaro Talens (1989, III: 280-281), Mercedes Alcalá Galán (2006: 183186) y Pedro Ruiz Pérez (2011: 199); también, indirectamente, por Francisco Javier Díez de Revenga (1995: 27) o José Manuel Trabado Cabado (2000: 69) cuando insisten en la necesidad de estudiar la poesía de Cervantes en su contexto narrativo, explicando que no se deben desgajar los poemas como si de unidades plenamente independientes se tratasen.

Nosotros, sin embargo, no estamos enteramente de acuerdo con este punto de vista. Creemos que debe destacarse que Cernuda está siendo tan anacrónico al hablar de incipientes monólogos dramáticos cervantinos como en sus otras ideas antes consignadas; lo mismo que es cernudiano el interés por el tema de España, también lo es el que le lleva a Browning y al monólogo dramático, que el poeta sevillano estudió repetidamente (en Pensamiento poético de la lírica inglesa y en Poesía y literatura) y que utilizó en varios de sus poemas tardíos más famosos e importantes; no debe perderse de vista, como dijimos, que este es uno de los últimos textos que Cernuda escribió, ya poco antes de 
morir, lo que pudo hacer que, especialmente turbado, se proyectase de modo particular en este ensayo.

Además, antes anotábamos que este tipo de explicaciones parten de la influencia que la crítica del Quijote comienza a ejercer aplicada a la poesía de Cervantes. Así, los poemas de nuestro autor empiezan a verse como sutiles construcciones geométricas articuladas dialógicamente en función de variados juegos de perspectivas, cayendo en el extremo contrario al de la crítica decimonónica: del mal poeta hemos pasado abruptamente al autor que se anticipa varios siglos a su tiempo y construye en sus poemas un alambicado entramado textual a partir de diversas citas y autocitas.

Es cierto que efectivamente Cervantes se vale de este artificio dialógico, cercano al monólogo dramático, en poemas como «Soneto al túmulo de Felipe II en Sevilla», pero de ello no nos parece que quepa inferir generalidad ninguna ni ver en los usos cervantinos la sofisticación que el aprovechamiento del monólogo dramático alcanza en los poemas últimos de Cernuda.

Sin embargo, solo desde este enfoque se entienden ciertas aseveraciones de la crítica reciente. Es el caso de la siguiente cita de Mercedes Alcalá Galán, sobre la que habremos del volver:

Otro ejemplo que quiero traer a estas páginas a propósito de la cita es el muy estudiado y a veces denostado por su «falta de calidad poética» poema de Lotario en la primera parte del Quijote: «En el silencio de la noche, cuando / ocupa el dulce sueño a los mortales», que plantea varias cuestiones interesantes sobre la citación de la lírica en la novela. En primer lugar, este soneto parece ser que tiene su fuente en un soneto de Petrarca; por lo tanto, otra voz y otro tiempo se hallan implícitos en el texto. En segundo lugar, se ha criticado repetidas veces la estética trasnochada del mismo, vaciada en moldes poéticos ya gastados y anacrónicos. De este modo se ha puesto en contacto a Cervantes con su soneto como si de una genuina composición lírica se tratara, y no lo es porque aunque en todo cumple con la idea del soneto lírico, es un poema citado. El autor ha roto en la ficción todo parentesco de autoría. Además, es el poema de un personaje, Lotario, que cuenta con dos «lectores» atentos en la ficción que van a buscar distintas resonancias en el texto según sus circunstancias e intereses. Camila y Anselmo van a sentirse implicados en la lectura de este soneto, van a participar activamente como oyentes-lectores, y van a actualizar dentro de la novela este acto de citación al ser sus receptores dentro del texto. Así, esos personajes van a aportar resonancias contextuales radicalmente distintas al soneto citado desde dentro de la ficción novelesca; por ello los juicios estéticos sobre la forma ya gastada de este soneto de corte petrarquista no van a poder aplicarse dentro del texto ya que este no está sujeto a la misma historicidad que su autor. Así pues, el criterio de exigencia de calidad artística, por razones obvias, no puede ser el mismo para Lotario que para Cervantes. Pero todavía la cosa se complica algo más pues sabemos que Cervantes reutiliza, recicla con variantes, este soneto en la jornada tercera de su comedia La casa de los celos. En su naturaleza de texto citado dos veces, ¿se trata del mismo soneto? o por el contrario ¿son dos sonetos distintos, dos citas, dos espacios textuales marcados por las implicaciones específicas de sus contextos? (Alcalá Galán, 2006: 191-192). 
Parece que tales explicaciones tienen por objeto principal negar el carácter arcaizante que muchas veces se ha atribuido a la lírica cervantina mediante una elaborada construcción teórica. El caso es que si acudimos al capítulo del Quijote al que se alude en el texto que acabamos de copiar, esto es, aquel en que se insertan los dos poemas de Lotario (I, XXXIV), vemos que, en nuestra opinión, su inclusión es circunstancial, y mínimo su peso en la trama; es decir, se trata de poemas fácilmente desgajables de su contexto: tanto que, como Alcalá Galán explica, el propio Cervantes lo hizo en otra ocasión. A la explicación de Alcalá Galán hemos de añadir otra más sencilla: Cervantes reutiliza, acomoda al texto un poema que había escrito previamente, y lo hace porque la fícción novelesca se lo permite y porque estima su propia composición hasta el punto de que más adelante volverá a utilizarla en otra obra suya.

Es cierto que algunos poemas de Cervantes (particularmente en el Quijote) solo pueden entenderse si sabemos en boca de quién están puestos: es el caso de los poemas que abren y cierran la primera parte de la obra, por ejemplo, o de los poemas que entona el propio Don Quijote. Nadie discute estos casos en concreto. Pero en un alto porcentaje, nos parece, los poemas intercalados no son más que añadidos muchas veces circunstanciales que Cervantes hace por el amor que tiene a la (y a su) poesía ${ }^{4}$. Suelen repetir estos críticos que Cervantes nunca publicó un libro de versos porque su poesía estaba pensada para incluirse entre su prosa (por ser, supuestamente, como venimos diciendo, una poesía pensada para representar la psicología de unos personajes y no la suya propia). Al margen de que esta inferencia parece dar excesivo relieve a la publicación de poesía en vida (algo que no hicieron ni Garcilaso, ni Fray Luis, ni San Juan, ni Góngora, por poner solo eximios ejemplos, y ello no quiere decir nada sobre las características de sus versos), nosotros creemos más bien que Cervantes pensó en incluir, en dar salida a su poesía entre su prosa porque nunca publicó un libro de versos, extremo este en el que estamos de acuerdo con Francisco Ynduráin (1985). Todo esto por no mencionar la teoría al respecto de Adriana Lewis Galanes, quien considera que Cervantes fue un poeta «cuyo culto a la Belleza y cuya estima del poema como registro de los más valiosos valores universales no le permitían rebajar la Poesía a un nivel de empresa comercial»... (Lewis Galanes, 1972: 18). Falta explicar, entonces, cómo es que Cervantes incluyó versos en todos y cada uno de los libros que publicó, sin olvidar su teatro en verso, el Viaje del Parnaso y los muchos poemas de circunstancias con los que saludó distintas publicaciones.

Los poemas de Cervantes incluidos en sus novelas casi siempre admiten una lectura autónoma y pocas veces dependen del contexto. Por volver sobre el mismo ejemplo, ¿qué hace que el soneto aludido sea de Lotario? Solo una cosa: que es Lotario quien lo recita. En vano se buscará una identificación psicológica más honda entre poema y personaje. El soneto habla de desamor, pero ello se debe más al modelo petrarquesco que se sigue que a la situación

4. Idea muy parecida a esta viene a defender José Montero Reguera (2004: 37-56). 
emocional de Lotario. Además, cuando se insiste en que la poesía de Cervantes no suele expresar los sentimientos de su yo, habitualmente se ignora que tampoco sucede así con gran parte de la poesía del periodo. Es decir, no es un argumento en favor de la teoría que ve en la poesía Cervantes monólogos dramáticos avant la lettre el hecho de que Cervantes no escriba lo que hoy llamaríamos una «poesía sincera», sencillamente porque esa poesía «sincera», precursores como Lope al margen, no se asienta sino con el Romanticismo.

\section{LOS SUPUESTOS DEFECTOS MÉTRICOS Y ESTILÍSTICOS DE CERVANTES}

Hemos venido viendo cómo una visión excesivamente artificiosa de la poesía de Cervantes surge como reacción contra una serie de ideas de raigambre decimonónica que habían presidido el estudio de los versos del autor del Quijote. De hecho, ni una ni otra opción debe satisfacernos. Llama la atención, no obstante, que, en su intento por legitimar la poesía cervantina, ningún crítico haya intentado responder a las graves acusaciones formuladas contra la poesía y la destreza poética de Cervantes.

Hacerlo no era difícil, pues ya Cernuda en su famoso y reseñado artículo había apuntado que Cervantes «dispone de toda la gama y variedad de versificación que era posible que entonces emplease» (Cernuda, 2006: 695); y Gaos (1974, I: 20), entre otros reproches sobre los que habremos de volver, que «Cervantes utilizó el endecasílabo en toda clase de combinaciones estróficas -tercetos, cuartetos, sextinas, octavas-, con soltura en nada inferior a la de los máximos poetas del Siglo de Oro». Lo cierto es que la descollante capacidad poética de Cervantes no puede aparecernos sino fuera de duda. Cervantes escribió, teatro incluido, un total de más de cuarenta mil versos; si acudimos solo a sus poesías sueltas y a las que intercaló en su prosa, nos encontramos con un corpus de aproximadamente doce mil. Dominó de forma absoluta las tradiciones castellana e italiana, y, así, escribió redondillas, tercetos, coplas reales, coplas mixtas, coplas de ate mayor, pareados, romances, romancillos, octavas reales, octavillas, endecasílabos sueltos, sextetos-lira, cuartetos-lira, liras, villancicos, canciones en estancias, canciones medievales, sonetos, zéjeles, serventesios, quintillas, seguidillas, glosas, silvas, décimas, perqués y cantares; manejó los versos más habituales de su tiempo (pentasílabos, hexasílabos, heptasílabos, octosílabos, endecasílabos y dodecasílabos) y todos los tipos de rima, y, por si fuera poco, ensayó formas estróficas tan raras y exigentes como la sextina y el ovillejo, todo esto por no citar la afición que sintió por piruetas formales como el estrambote, o, en especial, por los versos de cabo roto; es, de hecho, el representante por antonomasia en el marco de la métrica española en la utilización del ovillejo, el estrambote y el cabo roto (y no solo a final de verso) (Domínguez Caparrós, 2002). En su Métrica española, de hecho, Tomás Navarro Tomás alude a Cervantes al paso de casi todas las 
estrofas típicas de los Siglos de Oro (1995: 251-304). Se ha puesto en duda una faceta en la que Cervantes demostró repetidas veces su virtuosismo.

$\mathrm{Su}$ facilidad natural para la versificación y sus decenas de miles de versos perfectos deberían bastarnos para dudar de los versos hipermétricos o hipométricos que suelen afeársele. Como explicó Rojas (1916: L), «muchos de los que hallan incorrecta la versificación de Cervantes olvidan que, con el auxilio de aquella ciencia [la crítica textual], podrían rectificar las supuestas fallas de métrica». Pongamos solo un ejemplo del mal estado textual en que aún se encuentra la poesía de Cervantes. En la Numancia (I, v. 393), encontramos, según la lección de Sevilla Arroyo y Rey Hazas (2003: 932) (que es la que sigue Caballero Bonald (2005: 210)) un endecasílabo dactílico o de gaita gallega, «Estos tan muchos temidos romanos», que disuena profundamente en el famoso y bellísimo pasaje en el que se ve inserto (la conocida tirada que comienza «Alto sereno y espacioso cielo», puesta en labios de «España»-vv. 353-440-). Como es sabido, los endecasílabos dactílicos pueden combinarse de forma armónica únicamente entre sí; insertos en un conjunto de endecasílabos acentuados en sexta u octava, producirán efectos antirrítmicos casi siempre desaconsejables. En este caso, el verso «Estos tan muchos temidos romanos» es enmendado sagazmente por Rojas, que lee «Estos tan muchos tímidos romanos» Rojas (ed., 1916: 352), restituyendo en el verso la acentuación correcta. ¿Cómo saber que Rojas no ha intervenido ilícitamente en el poema de Cervantes? Porque los «tímidos romanos» del verso 393 forman sistema con los «valientes numantinos» del verso 396; dicha oposición, clarísima una vez advertida, no existe si seguimos la lectura de Sevilla Arroyo y Rey Hazas 5 .

El caso es que las habilidades versificatorias de Cervantes, en lo que respecta fundamentalmente a la prosodia del verso, han sido repetidamente puestas en solfa. Rodríguez Marín apuntó que «Quien tan suelta y garbosamente escribía la prosa, se encuentra desmañado y torpe por las dificultades materiales que para él ofrecía el verso [...] Cuéstale trabajo lo práctico de la versificación, y leyendo sus versos parece que le vemos titubear con desaliento» (Rodríguez Marín, 1935: XXV-XXVI). Unos años más tarde, Gerardo Diego (1948: 221) iba todavía más allá: «En cuanto a la impresión de torpeza, no puede ser, por desgracia, más evidente y continua. ¿Qué le pasa a Cervantes en cuanto empieza a versificar, que así pierde los estribos y se desazona a cada corcovo de su impaciente Pegaso de fina raza?». Gaos, por su parte, llega a poner en duda la vocación poética de Cervantes (vocación que Rojas y Diego creían incuestionable) y opina que «si escribió bastante poesía fue porque el verso era vehículo obligado en la época para una serie de géneros literarios [...] No, Cervantes no había nacido precisamente poeta» (Gaos, 1974, I: 9), afirmación esta con la que no podemos estar menos de acuerdo y que desmienten sencillamente el volumen total de la obra en verso de Cervantes y el hecho de que

5. Debe hacerse notar que en su exhaustiva y reciente edición crítica de la Numancia, Alfredo Baras (2009: 82) recoge en su texto la lección «tímidos». 
Cervantes escribiese poesía a lo largo de toda su vida, ininterrumpidamente, a diferencia de cualquiera de los otros géneros que cultivó. Gaos (1974, I: 15), al respecto de la técnica poética de Cervantes destaca «la torpeza con la que la maneja», sin pasar por alto sus «numerosos y graves defectos: así, pobreza de rima, falta de suavidad, uso frecuente de epítetos y frases hechas, exceso de retórica» (Gaos, 1974, I: 16).

\subsection{Las explicaciones tradicionales}

Antes de pasar revista al análisis de los reproches concretos que se han dirigido sobre diferentes versos de Cervantes, creemos interesante atender a las explicaciones que algunos críticos han dado de estas caídas prosódicas cervantinas, a la cabeza de los cuales se encuentra Gerardo Diego, quien ha provisto a los sucesivos estudiosos del más invocado argumento de defensa de los errores versificatorios cervantinos, a saber, que Cervantes tenía un oído justo y atinado para la recepción pero malo para la entonación, o, lo que es lo mismo, que era la suya la situación de quien «no acierta a cantar la nota que desearía y que sabe darse cuenta de la desafinación sin acertar a remediarla» (Diego, 1948: 228).

El argumento de Diego nos parece muy débil: para empezar, los versos de acentuación deficiente en Cervantes son una minoría entre los, recordemos, más de cuarenta mil que escribió, y, si las cosas fueran como Diego las pinta, deberían ser muchos más los versos inarmónicos de Cervantes. Por otra parte, Diego lleva hasta el extremo una metáfora habitual: que hablemos de la «afinación» de un verso no significa que haya en el ritmo poético nada que deba «afinarse». De hecho, las pautas de acentuación correcta de un verso no tienen nada que ver con una melodía que deba ser acordada, sino únicamente con un ritmo constante, bastante sencillo por otra parte. En poesía, además, ser capaz de reconocer un verso bien acentuado supone poseer las mismas cualidades que se requieren para escribirlo, y por eso el mejor aprendizaje de un poeta está en la lectura.

A pesar de la falibilidad de la explicación de Diego, esta ha sido comúnmente invocada. Adriana Lewis Galanes, tras citar a Diego, propone otra explicación a la supuesta impericia métrica de Cervantes. Según ella, Cervantes persigue antes la armonía de la idea que la armonía del verso, y se «permite la modificación de lo establecido como reglas del verso con tal que se sujete a un esquema armónico cuidadosamente elaborado por el intelecto» (Lewis Galanes, 1972: 20); es decir, que el valor acústico del poema se supedita a la estructura del poema. Habría que pedirle a Galanes que precisase qué entiende por «reglas del verso», y es que Cervantes empieza a publicar poesía bastante antes de que se escribiesen las preceptivas con arreglo a las cuales su poesía podría presentar ciertos errores. Lo que Galanes apunta, en definitiva, es que en la poesía cervantina «el verso cervantino carece de valor acústico «en 
sí»: [...] el vínculo no ocurre entre la voz y el grupo fónico, como es usual, sino entre el pensamiento (arquitectónicamente trabado) y el grupo fónico (rítmicamente dispuesto en subordinación a la armonía conceptual)» (Lewis Galanes, 1972: 26). A esto valdría replicar que los versos de Cervantes, como todos los versos que lo sean, no pueden carecer, en tanto que versos, de valor acústico. Lewis Galanes viene a decirnos que en la poesía de Cervantes el fondo se impone a la forma y que ello explica las supuestas deficiencias que esta presente. Pero la tensión habida entre pensamiento y realización fónica es consustancial a la poesía; Lewis Galanes parece dar a entender que un pensamiento elaborado implica y justifica una forma descuidada, lo que no puede ser menos verdadero. En cualquier caso, Lewis Galanes no detiene ahí su argumentación, y apunta una última explicación de la irregularidad prosódica del verso de Cervantes: según ella, Cervantes escribe sus poemas con su correspondiente melodía, de suerte que «la tonada le presta» al verso «la armonía acústica necesaria», de manera que no podamos juzgar, así, los defectos métricos de Cervantes porque «la cadencia de un verso cantado varía del hablado: adquiere valores acústicos ajenos a los esquemas fonológicos de la lengua» y «es imposible determinar la cadencia musical de los versos de Cervantes» (Lewis Galanes, 1972: 27).

Es decir, que los errores de Cervantes dejarían de serlo en virtud de una música que no podemos reconstruir. Esta conjetura de Lewis Galanes resulta aún más endeble que la anterior: que la convención literaria finja que los poemas pastoriles de La Galatea se cantasen con zampoña y caramillo no quiere decir en absoluto que Cervantes compusiese ningún tipo de música, como no lo hacía ningún poeta a la altura de finales del siglo XVI y principios del XVII: Lewis Galanes debería explicar en qué se basa para atrever una hipótesis tan alejada de lo que pensamos hoy día sobre la poesía de los Siglos de Oro. ¿Musicados por él mismo los poemas de Cervantes? Su idea, en fin, se apoya en un supuesto no solo no demostrado sino además indemostrable, en tanto que amparado en un testimonio desaparecido, que contradice todo lo que sabemos acerca de la poesía aurisecular.

Quizá sea un buen momento para abordar otra explicación que tradicionalmente se ha venido dando a las irregularidades métricas de Cervantes: su libertad. No puede extrañarnos que ciertas características de su obra se hagan depender de ella, después de haber escrito en un hermoso soneto: «Libre nací, y en libertad me fundo» (La Galatea, VI, «¿Quién dejará del verde prado umbroso?», v. 14), y de haber luchado y padecido por su libertad como él lo hizo. Así, si Cervantes rechaza ciertas convenciones rítmicas, lo hace porque descree de toda atadura. La última formulación de esta hipótesis se debe a Luis Alberto de Cuenca (2005: 211-212), quien explica que «esa brusquedad formal escondía en su fondo una libertad inmensa, una fuerza expresiva enormemente original y una riqueza inagotable en el ámbito del pensamiento y la invención». Es difícil negarle a Cervantes la originalidad, y, por lo tanto, la desprejuiciada libertad con que se acercó a la literatura, pero es discutible derivar de esto todas las características de su obra. Más adelante veremos 
hasta qué punto puede hablarse de «brusquedad formal» en Cervantes; lo que nos parece claro, como decíamos respecto de las teorías de Lewis Galanes, es que la «brusquedad formal» es absolutamente independiente de la «riqueza inagotable en el ámbito del pensamiento y la invención». De nuevo, parece que Cervantes hubo de sacrificar la corrección prosódica de sus versos para alcanzar dicha riqueza; pero, de hecho, ejemplos evidentes tenemos de poetas absolutamente originales y profundos en la invención y totalmente impecables técnicamente (Garcilaso, Góngora, Quevedo, etc.). Honestamente, debe apuntarse que si Cervantes alcanzó altas cotas en los planos del pensamiento y la invención, ello ni explica ni disculpa otras facetas menos brillantes de su poesía. Es decir, no hay ningún tipo de relación causa-efecto entre la técnica dificultosa y la creatividad temática: son, ya lo hemos dicho, aspectos independientes que, en nuestra opinión, deberían dejar de ser socorridamente aludidos en pareja.

Por último, contamos con la explicación de Jenaro Talens (1989: 274-277), quien reproduce la de Gerardo Diego y sigue muy de cerca la de Lewis Galanes, e insiste en la creación por parte de Cervantes de un ritmo estructural que se impone al ritmo versal, de forma que «subordina la métrica y la prosodia al equilibro estructural»: según Talens (1989: 278), lo que interesaría a Cervantes es la construcción armónica del poema y no tanto la de cada verso. Como explicamos antes, no vemos contradicción entre uno y otro, ya que ambas exigencias pueden satisfacerse simultáneamente. No obstante, llega a decir todavía Talens que Cervantes «señala su concepto del ritmo del arte, la relación entre las partes del poema y entre el poema y cada parte (eso que los teóricos de la vanguardia llaman el gran descubrimiento de Baudelaire y que de hecho inventó Cervantes)»(Talens, 1989: 277). Pero antes de comentar esta apreciación, demos cuenta de la última razón que, según Talens, explica la dureza prosódica de algunos poemas cervantinos:

Pese a todo lo dicho, resulta incontestable que muchos de los poemas cervantinos puedan ser calificados de malos (todo lo malos que pueden ser siendo de Cervantes), pero es un problema que incluso subraya la importancia de la aventura cervantina: cuanto más alto se atina, más grande es el yerro si no se acierta, y ese énfasis sobre el plano mental a veces se transforma en un muro contra el que se estrella el logro mental. Mientras Garcilaso, Herrera, Lope o Góngora dejan el verso como una marca sobre los ojos y los oídos, Cervantes busca impresionar nuestra capacidad intelectiva sin entrar por los sentidos. Eso más que un error es también una marca de fábrica. Existe en Cervantes una cierta desconfianza en la percepción sensible (Talens, 1989: 279).

Como vemos, nos encontramos ante una reivindicación de la poesía de Cervantes que, más que basada en la lectura atenta, actúa extrapolando determinados tópicos más o menos establecidos (lo que, por cierto, no los hace menos discutibles) en torno a la prosa cervantina o, como solemos apostillar, más bien al Quijote. Atribuir a Cervantes una innovación baudelaireana, nos 
parece, es una exageración muy discutible y muy difícil de demostrar; de hecho, por más que los poemas de Cervantes destaquen por su construcción estructural, sería engañarnos por completo afirmar que superan es ese aspecto a Garcilaso, Góngora, Lope o Quevedo. Este tipo de reivindicaciones exageradas de la poesía cervantina ¿a dónde quieren conducirnos? ¿A considerar que sus caídas se deben a que emprendiera una arriesgadísima revolución? Afirmar algo parecido sería, de nuevo, engañarnos completamente. En nuestra opinión, ni Cervantes se anticipó a Baudelaire ni aventajó a Garcilaso, Herrera, Lope o Góngora en lo que a «impresionar nuestra capacidad intelectiva» se refiere. Además, pretender que Cervantes descuidó los aspectos acústicos de su poesía porque desconfiaba de «lo sensible» se nos aparece, de nuevo, como una discutible e injustificable apreciación. Aducir, como hace Talens, un pasaje del episodio de la Cueva de Montesinos (Quijote, II, XXXIII, Talens, 1989: 279-280) no nos parece suficiente. Para empezar, deducir de un fragmento de la alucinación de un personaje loco de una novela humorística el pensamiento del autor real de dicha novela es absolutamente inviable; pero es que, además, esa idea de la desconfianza de lo sensible en el Quijote es excesivamente deudora de determinadas interpretaciones radicalmente románticas del texto, ha mucho ya puestas en cuestión. En el Quijote el lector no tiene duda nunca de qué es lo real, y la prueba más clara de ello es que el texto nos resulta cómico. Si realmente dudásemos de nuestros sentidos y nos preguntásemos verdaderamente, por aducir un conocido ejemplo, si la bacía es yelmo o baciyelmo, no nos divertirían la escena y los afanes del bueno de Sancho ${ }^{6}$. Hacer extensible a la poesía cervantina determinados tópicos referidos a su prosa ni mejora la poesía de Cervantes ni hace que la conozcamos y comprendamos mejor. ¿Cómo sostener un supuesto «descrédito de lo sensible» cuando Cervantes firma numerosos poemas que son un prodigio de musicalidad, frescura, ritmo y rapidez (puramente sensibles, pues), tal es el caso de los compuestos en hexasílabos, por ejemplo?

Los intentos por explicar, justificar o incluso transformar en virtudes los supuestos errores métricos y estilísticos de Cervantes no nos han llevado más que a acuñar un puñado de clichés (la dureza de oído entonadora, la supeditación de la forma al fondo, la supuesta tonada que acompañaba a la poesía o el descrédito de lo sensible) que, insistentemente repetidos, no nos han servido para aclararnos demasiado. Además, todas estas explicaciones parecen ignorar un hecho fundamental que no se ha subrayado nunca que sepamos, aunque no deja de ser una obviedad, y es que solo es en el endecasílabo cervantino en el que encontraremos lo que se ha venido llamando errores prosódicos y estilísticos (y está por ver, como ahora haremos, hasta qué punto cabe hablar de errores); las críticas que se hacen a Cervantes se circunscriben exclusivamente a su uso del endecasílabo y casi exclusivamente al Viaje del Parnaso,

6. Las páginas que nos parecen más agudas sobre este particular pueden leerse en Martínez Mata, 2008: 105-108. 
olvidando además que al tratarse de un poema burlesco una cierta irregularidad rítmica estaría completamente justificada. Para empezar, más abajo revisaremos con cuánta fidelidad sigue el endecasílabo cervantino los patrones rítmicos que Tomás Navarro Tomás ha singularizado como típicos del garcilasiano (Navarro Tomás, 1982: 139-147). ¿Pero, además, qué hay de los miles de versos de Cervantes de cinco, seis, siete, ocho y doce sílabas, en los cuales se encontrarán no más errores que en los versos de Lope de tales medidas?

Los supuestos defectos métricos y estilísticos cervantinos (y es hora ya de enfrentarnos con ellos y extraer las conclusiones pertinentes) deben, insistamos, circunscribirse al endecasílabo, lo que por supuesto no quiere decir que Cervantes no manejase con evidente e impecable soltura dicho metro, particularmente en sus sonetos (Montero Reguera, 2005: 35).

\subsection{Ricardo Rojas (1916)}

El primero en atacar el endecasílabo Cervantino fue Ricardo Rojas, aunque debe destacarse en su descargo que sus reparos siguen a unas muy cabales páginas en las que aclara muchas de las características de la prosodia y la ortografía cervantinas, exculpando a Cervantes de muchos de los errores que, con posterioridad a esas páginas de Rojas, comúnmente se le atribuyen todavía (Rojas, 1916: LXIII-LXVI). Cinco son los defectos estilísticos característicos que Rojas encuentra en el verso de Cervantes: 1) abundancia de cacofonías, 2) prosaísmo, 3) adjetivaciones excesivas hasta incurrir en ripio, 4) uso de «que» pleonástico y 5) abusos conceptistas.

Con respecto a las cacofonías, hoy estaríamos antes dispuestos a considerarlas acertados ejemplos de recurrencia fónica, como en los siguientes versos (Rojas, 1916: XXVII), pues colorean la expresión y acendran su potencialidad mnemotécnica, aunque sobre este punto habremos de volver al hilo de las consideraciones de Rodríguez Marín al mismo respecto:

1. Que este Bartolomé menor merece [Galatea, VI, «Canto de Calíope», v. 751].

2. Con que del gentil Tajo al fértil Reno [Galatea, VI, «Canto de Calíope», v. 781].

3. Tu Conde de Elda en todo tan dichoso [Galatea, VI, «Canto de Calíope», v. 783].

4. Los tristes teucros tanto se afligieron [Galatea, VI, «Tal cual es la ocasión de nuestro llanto», v. 74].

Parece incompatible atacar estos versos y sin embargo defender el primor estilístico de otros como «un nocturno rumor de ruiseñores» (J. L. Borges) o «si los senos son olas, si son remos» (B. de Otero), por no acudir a ejemplos más próximos del tipo de "Mientra el franco furor fiero se muestra» (G. de Cetina) o «Mas, ¡ay!, que con mis males más me ofendo» (F. de Herrera). 
Aún más sorprendente, si cabe, nos aparece la acusación de prosaísmo que Rojas vierte sobre versos como los que siguen (Rojas, 1916: XXVII), en los que un lector de nuestro tiempo no apreciará prosaísmo de ningún tipo (Gerardo Diego (1948: 230) se referirá a algunos de estos versos que Rojas considera «no sabemos por qué, pura prosa»):

1. Sabed que es el licenciado Daça [Galatea, VI, «Canto de Calíope», v. 128].

2. Del largo canto mío ahora hago [Galatea, VI, «Canto de Calíope», v. 874].

3. La sana voluntad de un pecho hidalgo [Galatea, IV, «Si yo dijere el bien del pensamiento», v. 30].

4. Que en vituperio del amor se forma [Galatea, IV, «Sin que me pongan miedo el hielo y fuego», v. 10].

Lo cierto es que quizá este tipo de reparos nos digan más del crítico que la formula y de sus gustos literarios que de la propia poesía cervantina. Tampoco podemos sentirnos muy de acuerdo con Rojas cuando critica determinadas «adjetivaciones excesivas»:

Puesto que después supe que con alta, magnifica elegancia milagrosa, donde no sobra punto ni le falta.

[Viaje, VIII, vv. 367-369]

Efectivamente, tres adjetivos (que subrayamos) acompañan al sustantivo «elegancia», lo que de suyo no constituye ningún defecto (de nuevo, sobre este particular habremos de volver un poco más abajo: baste añadir por ahora que análogos ejemplos se encuentran en los mejores poetas: baste recordar el «Chiare, fresche e dolci acque» de Petrarca); los tres adjetivos, además, aparecen gradualmente ordenados (alta, magnífica, milagrosa), todo lo cual viene sin duda a actuar como recurso intensificador.

Llenó del gran bajel el gran vacío el gran Francisco de Rïoja al punto que saltó de la nube en el navío.

[Viaje, III, vv. 124-126]

Es evidente ahora la repetición de «gran», que no resulta estilísticamente primorosa, pero tampoco, pensamos, censurable; además, no debe leerse fuera del contexto paródico del combate entre los buenos y los malos poetas en el que se inserta, y en el que esta adjetivación distanciada y ligera no constituye bajeza ninguna.

Cortesano, galán, sabio, discreto,

callado, liberal, manso, esforzado,

de aguda vista aunque de ciegos ojos.

[Galatea, IV, «Salga del limpio, enamorado pecho», vv. 29-31] 
Aquí Rojas, pensamos, se equivoca por completo; los versos de Cervantes fluyen con vigor, fuerza y gracia; criticar estos versos por estar construidos a base de yuxtaposiciones equivaldría a atacar algunos otros tan inopinables como «mostrarse alegre, triste, humilde, altivo / enojado, valiente, fugitivo, / satisfecho ofendido, receloso», pertenecientes al «Soneto 126» («Desmayarse, atreverse, estar furioso») de las Rimas (1609) de Lope de Vega.

Ligero y más movible que la luna que ni estuvo, ni está, ni estará queda (Rojas, 1916: XXVIII).

De nuevo nuestro autor se muestra exagerado en la queja: la repetición verbal del segundo verso, que a él parece incordiarle, resulta enérgica, honda, actúa muy bien como contenida hipérbole, puede justificarse como la reminiscencia cancioneril que es, y todo ello sin olvidar su evidente deje garcilasiano («está y estará tanto en mi clavada», «Égloga III», v. 7).

La siguiente acusación que vierte Rojas sobre Cervantes es la de hacer uso inadecuado del «que» pleonástico:

Que así el suelo sabrá que sabe el cielo que el renombre inmortal que se desea

[«A Don Diego de Mendoza y su fama», vv. 12-13]

Lo cierto es que resulta un rasgo de estilo bastante inocuo, típico de Cervantes, que acerca el discurso a una natural oralidad y da al verso un especial sabor popular («Tu calle ya no es tu calle, / que es una calle cualquiera / camino de cualquier parte», escribió M. Machado); es, además, completamente dudoso que los dos versos que acabamos de copiar fueran a mejorar por eliminar el que con que principian, como parece sugerir Rojas.

\footnotetext{
Que, cuanto con mayor rigor sentencia, ¿qué puede más su limitada suerte que deshacer la liga y nudo fuerte, que a cuerpo y alma tiene en connivencia? [La entretenida, I, vv. 543-546]
}

La utilización deliberada de «que» anafórico acaso pueda ser objeto de cierta crítica (aunque de nuevo nos parece poco motivo para impugnar estos versos), pero lo que debe destacarse es que, aunque Rojas parece no advertirlo, ninguno de estos «que» es pleonástico, lo que queda de manifiesto si se busca el contexto en que se enmarcan. El primero es consecutivo; interrogativo, el segundo; comparativo, el tercero; adjetivo, el cuarto.

A la última acusación de Rojas, la de conceptismo, ha respondido en fechas recientes el profesor Montero Reguera con claridad meridiana. Estos versos que siguen, 
Mas tan sin fuerzas siento mi fuerza en esto que será forzoso

[Galatea, IV, «El vano imaginar de nuestra mente», vv. 39-40];

que Rojas tilda de «tartamudeos pueriles» (Rojas, 1916: LXIX), sin embargo, al verse «insertados en la tradición poética cancioneril muy presente en el texto, cobran nueva luz, pues se trataría [este tropo] de un políptoton o derivación, figura retórica habitual en la poética cancioneril, que se reitera a lo largo de las diez estancias que constituyen esta canción de ascendencia garcilasiana» Montero Reguera (2011: 256). Es decir, lo que parece un defecto, convenientemente contextualizado, puede dejar de serlo.

A decir solo dél y cantar cuanto

canto de los ingenios más cabales

[Galatea, VI, «Canto de Calíope», vv. 174-175]

Copiamos finalmente este último ejemplo, entre los seleccionados por Rojas como muestra de torpe conceptismo, por considerarlo, bien al contrario, diestra manifestación del aprovechamiento de los recursos fónicos que brinda al poeta el encabalgamiento: esta inteligente paronomasia «cuanto / canto» nos parece ejemplo a seguir antes que demostración evidente de ninguna clase de error. De hecho, también se lo pareció a todo un Meléndez Valdés, que se valió de casi idéntico recurso en su Oda XXXIII, «Que no son flaqueza la ternura y el llanto», en cuyos versos 47 y 48 leemos: «en su suerte fatal, sensible tanto / cuanto he casos más ásperos sufrido».

Salta a la vista, para nosotros, que las acusaciones de Rojas resultan hoy más bien injustificadas y un tanto enigmáticas.

\subsection{Francisco Rodríguez Marín (1935)}

El siguiente crítico que puso de relieve los defectos del verso cervantino, acudiendo a ejemplos concretos y no a vagas e injustas generalizaciones, fue nada menos que Francisco Rodríguez Marín, maestro de cervantistas, en el capítulo segundo de su monumental edición del Viaje del Parnaso (1935). Tras destacar cómo Cervantes «se encuentra desmañado y torpe por las dificultades que para él ofrecía el verso» (Rodríguez Marín, 1935: xxv), y referirse a «la abundancia de versos flojos y desmayados, y el revesado hipérbaton, y las sinalefas obstruccionistas» (Rodríguez Marín, 1935: XXVI), apunta una opinión muy interesante, pues «de los mismos defectos formales que en sus obras pueden señalarse hoy, los unos no lo eran en los siglos XVI y XVII, y los otros se advierten con tanta o mayor frecuencia [...] en las demás poesías de aquella época» (Rodríguez Marín, 1935: XVII).

De los defectos que Rodríguez Marín primeramente señala (uso irregular de «h», que a veces se aspira y a veces no; uso de consonancias que hoy ya 
no son tales; uso injustificado de diéresis y sinéresis; uso excesivo de endecasílabos yámbicos; uso de hipérbatos violentos; $\mathrm{y}$, por último, uso excesivo de la adjetivación) no parece tomarse ninguno demasiado en serio, y solo en una segunda fase de análisis se referirá a los problemas que él considera verdaderamente graves del verso cervantino.

Respecto del primer problema, destaca Rodríguez Marín cómo Cervantes juega a su gusto con el fonema $/ \mathrm{h} /$, optando unas veces por una realización muda y otras por una aspirada, según le convenga al metro. Así, conviven en el Viaje versos como «Cuando entraba en el puerto la hermosa» (I, v. 163) o «Desta manera comenzó a hablarme» (I, v. 201), que exigen una realización consonántica de «h», con otros tales como «Yo de tu hermosa luz, y clara y rica» (II, v. 67) y «Sacó otra vez a Proserpina hermosa» (II, v. 182), donde la exigidas sinalefas respectivas «tu-her»y «na-her» dejan a las claras su realización muda.

Este criterio cambiante de Cervantes no puede ni debe ser criticado, porque obedece a la sensibilidad lingüística mayoritaria a la sazón. Sabido es que Garcilaso siempre aspira la «h» (en inicial, y si etimológicamente proviene de una «f» inicial latina), y que dicho ejemplo será largamente imitado a lo largo del siglo. Sabido es que la poesía genera una serie de prácticas convencionales que no tienen por qué corresponderse con el estado de la lengua oral. Aunque en el habla popular madrileña se supone que en este momento (principios del siglo XVII) ya es residual la aspiración de la «h», lo cierto es que no sucede así en toda la península, y Nicolás Dávila, en su Compendio de Ortografía castellana (Madrid, 1631) hace notar que «la $h$ es letra gutural, y propiamente no es letra, sino aspiración; y así les sirve de licencia poética este conocimiento a los poetas para el número de las sílabas en sus metros, pues unas veces la ponen por letra para aumentar una sílaba, y otras la quitan para que tenga una menos» (Rodríguez Marín, 1935: XXVIII). Cervantes, en definitiva, actúa como muchos escritores de su época (Menéndez Pidal, en su Manual de gramática histórica española (1940: 121), cita el caso de Alonso de Ercilla, en quien a la altura de 1578 conviven lo mismo «donde más resistencia se hacía»-con «h» aspirada- y «en consejo de guerra haciendo instancia»-con «h» muda-).

En lo que se refiere al segundo reparo con que Rodríguez Marín impugna a Cervantes, esto es, la utilización de consonancias que hoy no son tales, supone tal reproche algo así como afearle a Cervantes hablar la lengua de su siglo y no la nuestra. Rodríguez Marín es consciente de que carece de fundamento considerar esto como una rémora de la poesía cervantina, pues si Cervantes rimó «dignos» con «sietemesinos» (Viaje, II, v. 231), o «perfectos» con «sonetos» (Viaje, I, v. 258) fue porque en el momento era efectiva y general la simplificación de los grupos cultos, solo recuperados dos siglos más tarde, y ya había dicho Juan de Valdés en su Diálogo de la lengua (h. 1535) que «cuando escribo para castellanos y entre castellanos siempre quito la $g$ y digo sinificar [...], dino, y no digno, y digo que la quito porque no la pronuncio» (Valdés, 2008: 147). 
Destaca Rodríguez Marín un uso bastante habitual en Cervantes y menos frecuente hoy, el de la rima idéntica. Por poner un ejemplo, copiemos estos dos tercetos (La entretenida, I, vv. 539-552): «Tu duro alfanje a mayor mal se extiende / pues un espirtu en dos mitades parte, / joh milagros de amor que nadie entiende! / Que del lugar de do mi alma parte, / dejando su mitad con quien la enciende, / consigo traiga la más frágil parte.». En estos casos, se aprovecha la coincidencia en una misma forma (parte) de tres palabras distintas con diferentes etimologías: aquí parte es sustantivo ('porción'; < PARS, PARTIS), y forma personal del verbo partir (< PARTĪRE) empleado en dos de sus sentidos principales, ('dividir' y 'emprender viaje'). Es decir, estamos ante lo que la poética trovadoresca clasificaba como mot equivoc, esto es, rima entre dos formas idénticas con distinto significado, lo que era considerado ejemplo de rims cars ('rimas difíciles'). Cuando Cervantes juega con este tipo de rima está, antes que nada, demostrando su habilidad técnica. Luis Alfonso de Carvallo, en su Cisne de Apolo (Medina del Campo, 1602), encarecía este tipo de rima diciendo que «ningún vocablo puede ser consonante de sí mismo, si no es en diferente sentido; que entonces antes es galantería» (Díez Echarri, 1970: 121).

Es cierto que, como explica Rodríguez Marín, no falta en el Viaje algún caso en que, en lugar de esta rima en diferente sentido, hallemos rimas absolutamente idénticas («ella» se rima con «ella» en IV, vv. 80, 84; «estaba» con «estaba» en VII, vv. 248, 250), o, lo que es lo mismo, en vez de ante un mot equivoc nos encontramos con un mot tornat (repetición en la que no hay variación de sentido), uno de los defectos típicos asimismo consignados por las poéticas trovadorescas. No obstante estos casos, podemos afirmar que de hecho son muy raros en la poesía de Cervantes; tanto, que pueden contarse con los dedos. Además, a pesar de que ha sido esta práctica condenada por la preceptiva, como hemos visto, no nos faltan ejemplos de su uso: la sextina, por ejemplo, lo tiene por norma; José María Micó ha inventariado brillantemente su uso en poetas del momento como Boscán, Cetina, Garcilaso y Herrera, entre varios otros (2008: 21-50); y, por último, es práctica que ha sobrevivido hasta nuestros días (ejemplo muy famoso al respecto es el poema «Arte poética», de Jorge Luis Borges, incluido en El hacedor, trenzado únicamente con rimas idénticas).

Llama la atención también Rodríguez Marín sobre algún caso en que Cervantes «consuena defectuosamente» (Rodríguez Marín, 1935: XXxi) y esgrime como ejemplo la rima de «veinte» con «frente»y «gente» (Viaje, VIII, vv. 95, 97 y 99); pero, en realidad, este tipo de rima, que hoy conocemos como «consonancia imperfecta», era y es de uso común (Lope de Vega, por ejemplo, consuena «velo» y «vuelo» en La Filomena (Domínguez Caparrós, 2000: 113)); el propio Rodríguez Marín anota cómo Leonardo de Argensola hace rimar «renta» y «treinta» (Rodríguez Marín, 1935: XXXX-XXXII). Cabe añadir que el jesuita Juan Díez Rengifo, autor de una famosísima Arte poética española (Salamanca, 1592), no considera indispensable la consonancia perfecta (Díez Echarri, 1970: 124). 
El siguiente uso defectuoso que Rodríguez Marín destaca en el verso cervantino es el de la diéresis, que Cervantes utiliza de vez en cuando en el Viaje («Un quídam Caporal italïano», I, v. 1; «Tú, Pedro Mantüano el excelente», VII, v. 307; «Julián de Amendárez no rehúsa», VII, v. 310; «Zapardïel famoso por su pesca», VII, v. 356; «Y alegre recibí a Justinïano», VIII, v. 399). Ahora bien, como otras veces antes, este uso no se da en los poemas cervantinos con más profusión que en los de cualquier otro poeta de su tiempo (Garcilaso y Herrera, por ejemplo), y ya no digamos de Góngora (por poner solo dos ejemplos: «Donde espumoso el mar siciliano», «Un torrente es su barba impetüoso» vv. 25 y 61 de la Fábula de Polifemo y Galatea), en quien son frecuentísimas las diéresis. Las poéticas del momento se limitan a recomendar que no se utilicen excesivamente, y con este consejo se aviene la práctica cervantina (Díez Echarri, 1970: 131).

A continuación, Rodríguez Marín afea a Cervantes la utilización del efecto contrario, esto es, la sinéresis. Hemos de repetir lo mismo: se trataba de una práctica habitual a la sazón, y puede rastrearse en cualquier poeta del momento (es frecuente, por ejemplo, que en Garcilaso ía deba leerse ia, como en el famoso verso «mas con la lengua muerta y fria en la boca», «Égloga III», v. 11), de modo incluso más exagerado que en Cervantes; y es que nuestro poeta, de hecho, nunca forzó la repetición en un mismo verso de una palabra de modo que una de las veces deba leerse abreviada mediante una sinéresis, pero la otra no. Es decir, Cervantes nunca escribió versos como este de Lope: «O se/an justos, Fabio, o sean injustos» (Burguillos, «Si se han de tener celos», v. 1); ni tampoco como estos otros de Góngora: «Ellas ponian el dedal / y yo poní/a la aguja» («Ahora que estoy de espacio», vv. 7-8) (Rodríguez Marín, 1935: XXXIV).

Seguidamente, Rodríguez Marín se refiere al uso que Cervantes da a los endecasílabos yámbicos (endecasílabos de cinco acentos, uno en cada sílaba par: «en tiérra, en húmo, en pólvo, en sómbra, en náda»), aunque él mismo reconoce que «bien mirado, su uso no merece tacha» (Rodríguez Marín, 1935: XXXVI). Estos endecasílabos, por ser de acentuación muy constante, pueden resultar excesivamente pesados si se usan repetidamente («Mandóme el dios parlero luego alzarme», Viaje, I, v. 199; «Las sacras musas fuerte amparo tienen», Viaje, II, v. 213; «Llenó del gran bajel el gran vacío», Viaje, III, v. 124, etc.). Cervantes distribuye unos cuarenta versos de este tipo lo largo de un poema de más de tres mil, y nunca en series consecutivas, de modo que respeta impecablemente los cánones al efecto.

Otra rémora que Rodríguez Marín encuentra en la poesía de Cervantes es el uso abundante del hipérbaton. El reproche, como más arriba nos pasaba con Rojas, acaso nos diga más del gusto literario clasicista de Rodríguez Marín que de las características versificatorias de Cervantes, que en este punto, de nuevo, se limita a seguir el aire de su tiempo. Si, efectivamente, Cervantes escribe «Donde con alta de soldados gloria» (Viaje, I, v. 142) o incluso «De Guevara Luis Vélez es el bravo» (Viaje, II, v. 167), lo cierto es que ni estos ni otros ejemplos que Rodríguez Marín agavilla (Rodríguez Marín, 1935: 
XXXVII-XXXVIII) resultan ni remotamente tan violentos como los que todos recordamos de Góngora; Cervantes no es de hecho un poeta oscuro, ni dado especialmente al hipérbaton: recordemos que su poeta favorito siempre fue Garcilaso, y esa misma línea formal sigue la mayoría de sus versos. Incluso en Lope («De la abrasada eclíptica que ignora, / intrépido, corrió las líneas de oro / mozo infeliz, a quien el verde coro / vio sol, rayo temió, difunto llora», La Circe, «De la abrasada eclíptica que ignora...», vv. 1-4) pueden encontrarse ejemplos más violentos de hipérbaton.

Con Rojas, el siguiente defecto que Rodríguez Marín encuentra en Cervantes es que «califica con tres y hasta cuatro adjetivos algunos sustantivos», como en el caso de «De un copioso, corriente, amargo río» (Viaje, V, v. 12) o «de aquellos [poetas] blancos, tiernos, dulces, blandos» (Viaje, I, vv. 91-92), pero él mismo se responde agudamente aduciendo ejemplos idénticos de los poetas más ilustres, desde Lope («Suprema, ínclita, insigne y alta cumbre», en Jerusalén conquistada, III, v. 50) hasta Petrarca («Fresco, umbroso, fiorito e verde colle», Canzoniere, v. 1 del poema homónimo) pasando por Fray Luis («Un día puro, alegre, libre quiero», de su «Oda a la vida retirada», v. 27) (Rodríguez Marín, 1935: XL).

Analizados todos estos inconvenientes menores, finaliza su recuento Rodríguez Marín refiriéndose a aquellos que considera especialmente graves hasta el punto de poner en entredicho seriamente las virtudes poéticas de Cervantes. Se trata de versos «enfermos», ya por «no tener los acentos en su sitio», ya por darse «sinalefas obstruccionistas», siguiendo la clasificación de Eduardo Benot, autor de un Hospital de versos incurables (Rodríguez Marín, 1935: XLI). Para empezar, pone ejemplos de versos mal acentuados, y cita:

Fue en mis alforjas mi repostería (Viaje, I, v. 113)

Donde el poder de la naturaleza (Viaje, III, v. 425)

Verme en medio de una ciudad famosa (Viaje, VIII, v. 249)

Los dos primeros versos, según Rodríguez Marín, son sáficos incompletos, pues a un primer acento en cuarta (alforjas y poder, respectivamente) no sigue un acento en octava. Sucede, sin embargo, que al ser las dos palabras finales de ambos endecasílabos de cinco sílabas («repostería» y «naturaleza»), su propia longitud determina la aparición de un acento secundario que viene a suplir la ausencia de una sílaba tónica. Es decir, que podemos (y de hecho así lo hacemos) leer «repostería» como «rèpostería» y naturaleza como «nàturaléza» sin violentar el verso. Aunque este tipo de versos sean raros, no son ni mucho menos inarmónicos ni tampoco insólitos; Gerardo Diego (1948: 229), refiriéndose a estos mismos dos ejemplos dice que «no nos disuenan». Además, pueden aducirse los clásicos ejemplos de Dámaso Alonso en Poesía española: así, «Esa montaña que, precipitante» de Góngora y «Yo insomne, loco, en los acantilados» del propio Gerardo Diego (Alonso, 2008: 84-85), versos ambos en los que a un acento en cuarta no sigue otro propiamente dicho en octava, sin que nadie haya acusado ni a sus autores ni a dichos versos de 
flojedad. Es más, Gonzalo Correas, en su Arte grande de la lengua castellana (Salamanca, 1626), explica perfectamente este procedimiento acentual (Díez Echarri, 1970: 136). No acaban aquí los ejemplos, porque de idéntico tipo de verso hicieron uso Garcilaso: «Un campo lleno de desconfianza» («Canción IV», V. 89) «¿Algunos premios? ¿O agradecimientos?» («Elegía I», v. 91) y Fray Luis «Se echó de pechos ante tu presencia» («Del conocimiento de sí mismo», v. 101).

El tercero de los endecasílabos de Cervantes copiados, «verme en medio de una ciudad famosa», responde a una acentuación poco ortodoxa pero no desconocida: los acentos recaen aquí en tercera y octava sílabas, lo que viene a ser algo así como una fusión entre las acentuaciones melódica y sáfica. Como indica Tomás Navarro Tomás (1982: 92-93), este tipo de endecasílabo fue utilizado ya por Garcilaso («por testigo de cuanto os he encubierto», «Canción II», v. 29) y también por Juan Ramón Jiménez («que caía cual en su propia fuente»). Aunque el verso no pueda adscribirse a alguna de los tipos endecasilábicos típicos, no hay nada, en fin, que pueda reprochársele desde un punto de vista prosódico.

Contó cuando volvió el poeta solo (Viaje, I, v. 22)

Junto a mí se sentó y su voz envía (Viaje, I, v. 292)

Cuatro vienen aquí en poca distancia (Viaje, II, v. 238)

Todos estos versos presentan la misma estructura y el mismo pretendido defecto: la sexta sílaba métrica de cada uno de estos versos, tónica, está formada por la unión en sinalefa de dos sílabas fonológicas («vió-el», «tó-y», «quí-en», respectivamente). No es este obstáculo mayor, y, otra vez, no faltan ejemplos similares en otros poetas del momento. Garcilaso está en el mismo caso cuando escribe «de tus consejos y íntimos secretos» («Elegía I», v. 65); Góngora, con «Y de la barba al pie escamas vestido» («De los Marqueses de Ayamonte, cuando se entendió pasaran a Nueva España», v. 2) o «Que no la registre él y yo no envidie» («Qué de invidiosos montes levantados», v. 18); el propio Meléndez Valdés utiliza el mismo tipo de sinalefa en versos como «nada miro, nada hallo que me cause» («A Jovino el Melancólico», v. 37); todo ello sin olvidar al Conde de Torrepalma: «¿qué ventura bastó $a$ la soberana?», «mientras admiran su áspero desierto» (Deucalión, vv. 77 y 175). Aunque se trata de una sinalefa violenta, no por eso es inválida ni mucho menos imposible; y, de nuevo, aunque aparece en Cervantes, lo hace esporádicamente. El propio Gerardo Diego (1948: 230) dijo que «la sinalefa de la sexta sílaba no nos estorba».

El siguiente verso herido que Rodríguez Marín destaca es el siguiente: De andar de una en otra encrucijada (Viaje, soneto inicial, «El autor a su pluma», v. 8); pero él mismo responde a su reproche, haciéndonos advertir de nuevo la necesidad de una profunda revisión textual de la poesía cervantina: «Si Cervantes, y así lo sospecho, escribió de en una en otra, al uso vulgar, como repetidamente en el Quijote [...], sería buen verso este». 
Los versos que siguen, sin otra indicación, «por flojos y desmayados merecen tacha» (Rodríguez Marín, 1935: XLII):

Juntos aquí. ¡Oh par sin par! En estos (Viaje, II, v. 212)

Ese es hijo de Apolo, ese es hijo (Viaje, II, v. 307)

Que no sé en qué, o cómo, o cuándo hizo (Viaje, III, v. 353)

Hasta aquí no he invocado, ahora invoco (Viaje, V, v. 88)

Esta tierra habité, hijo, le dije (Viaje, VIII, v. 287)

El primero de los versos no presenta más inconveniente que un hiato entre las sílabas cuarta y quinta, pero no se trata de un hiato violento, y convertirlo en sinalefa supondría incurrir además en el presunto defecto que Rodríguez Marín llamaba «sinalefa obstruccionista»; en el segundo verso, aparece de nuevo un hiato entre las sílabas séptima y octava que viene exigido por la correcta acentuación del verso; la separación fónica que se establece a ambos lados de la coma va bien además para enfatizar la separación que el verso plantea: «Ese es hijo de Apolo, ese es hijo / de Calíope musa» (Viaje, II, v. 307308); el tercer verso es absolutamente impecable y resulta difícil conjeturar qué veía de malo en él Rodríguez Marín; el cuarto verso debe silabearse como sigue: «Has ta-a quí no-he-in vo ca do-a ho ra-in vo co», donde no apreciamos mayor dificultad que una sinalefa de tres vocales: «no-he-in»; aunque este tipo de sinalefas siempre es algo violento, en este caso se aviene a la norma que las rige, pues, siguiendo una de las tres posibilidades válidas, están dispuestas las vocales siguiendo un orden de apertura descendente (Domínguez Caparrós, 2000: 62); el quinto y último verso, de nuevo, no presenta dificultad ninguna.

Siguen ahora algunos casos dispersos. El verso: «Desta manera comenzó a hablarme (Viaje, I, v. 201)» es irreprochable, habida cuenta de que debe leerse la «h» como aspirada, punto que ya no nos extraña y sobre el que no volveremos.

Estos otros dos versos:

Porque tú ¡oh envidia! Aquí tu rabia dobles (Viaje, III, v. 465)

Deja el cielo ¡oh amistad! O no permitas (Quijote, I, XXVII, «Santa amistad, que con ligeras alas», v. 9)

presentan ambos sinalefas de tres vocales («tú-joh!-en» y «lo-joh!-a», respectivamente), pero, igual que antes, se trata de dos órdenes válidos, pues el primero es ascendente (de vocal más cerrada a más abierta) y el segundo descendente (de vocal más abierta a más cerrada), y permiten su pronunciación en una sola sílaba (Domínguez Caparrós, 2000: 62).

Estos dos versos presentan para Rodríguez Marín sendas cacofonías:

Era de ingenio cabalmente entero (Viaje, I, v. 16)

Gritó: ¡Todos abajen la cabeza! (Viaje, VII, v. 230),

pero lo cierto es que tales repeticiones consonánticas son para nosotros, como apuntamos en otro lugar, un mérito y un ejemplo de hábil recurrencia fónica 
antes que cualquier tipo de rémora. No son muy distintos estos versos de aquel tan celebrado y hermoso, «Infame turba de nocturnas aves», del Polifemo de Góngora, que, acaso aplicando el mismo rasero de Rodríguez Marín, también pueda ser tildado de cacofónico.

Dos son, finalmente, los defectos con que concluye su exhaustiva enumeración Rodríguez Marín: una consonancia interior (una sola, «Que dais de vuestra providencia muestra» (Viaje, IV, v. 369), en un poema de más de tres mil versos) y «hasta ocho o diez tercetos en que el verso segundo es asonante del anterior y del posterior» (Rodríguez Marín, 1935: XLIII). El segundo defecto es fácilmente refutable, pues no hay poeta del tiempo en que no se hallen idénticas asonancias: Garcilaso las presenta por doquier, y aun en un caso más grave, aplicando la misma vara de medir, tal es nada menos que entre los seis primeros versos de una octava (en la «Égloga III» hay ejemplos de sobra: vv. $33-38 ; 73-78 ; 105-110 ; 145-150 ; 265-270 ; 273-278)$. Con lo que respecta al primero, si efectivamente alguna vez fue un defecto, hoy ha dejado de serlo por completo (además, Garcilaso también se sirvió de ese mismo tipo de rimas internas, como en «estoy cantando yo, y está sonando»-«Canción IV», v. 85-; hoy, como apuntábamos, son moneda corriente, un efecto buscado: por poner solo un ejemplo, puede citarse dos versos de Blas de Otero, uno de triple consonancia interna, «Inconsolablemente. Diente a diente» (Ángel fieramente humano, «Ciegamente», v. 5), y otro, aún más curioso, de quíntuple asonancia interna, "por ola y ola y ola en ronda y ronda» (En castellano, «La soledad se abre hambrientamente,...», v. 7).

\subsection{Gerardo Diego (1948)}

Ya hemos revisado muchas de las ideas de Diego, y nos queda ahora solo atender a los reproches métricos que formula. No serán demasiados, pues las más de las veces recoge ejemplos de Rojas o Rodríguez Marín a los que ya hemos atendido. Hay un punto, no obstante, en que se aparta claramente de sus predecesores. Afirma: «en Cervantes el verso bueno es excepcional, lo contrario que en todo auténtico poeta» (Diego, 1948: 216). Y, después, aludiendo a Ricardo Rojas (quien había dicho, refiriéndose a los malos versos de Cervantes, que «no es difícil hallar otros tan malos en Lope, Calderón, Herrera y Ercilla»), responde: «No. Ni en Lope ni en Herrera [¿sí en Calderón y en Ercilla?, nos preguntamos] encontraremos una estrofa entera como la que sigue» (Diego, 1948: 216), y a continuación copia dos pasajes tomados de La Galatea: el primero tomado del libro IV («El vano imaginar de nuestra mente», vv. 49-64); el segundo, del libro III («Cielo sereno, que con tantos ojos»», vv. 119-130): 


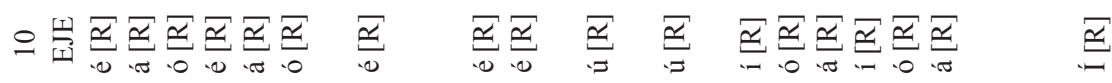

a

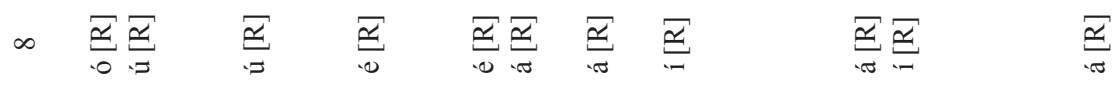

- $\quad \underset{0}{\mathbb{\Xi}}$

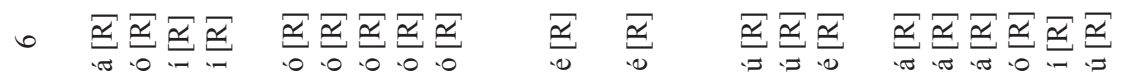

in $\quad \frac{\mathbb{S}}{0}$

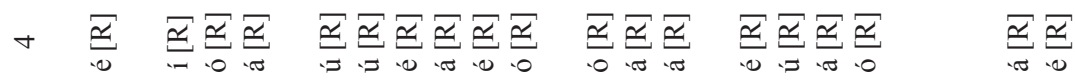

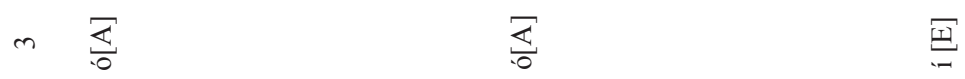

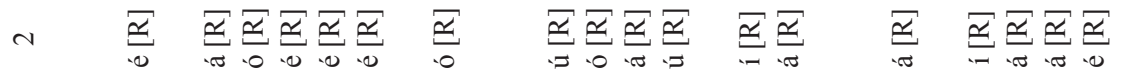

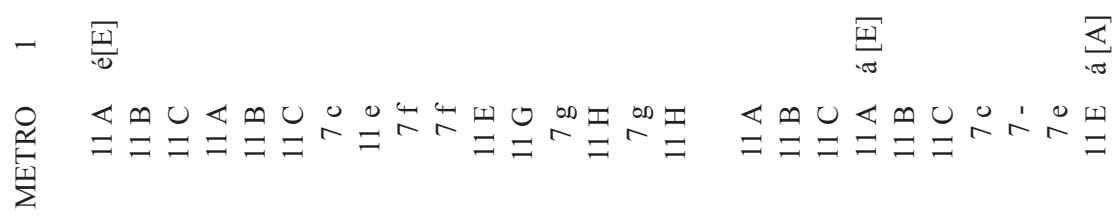

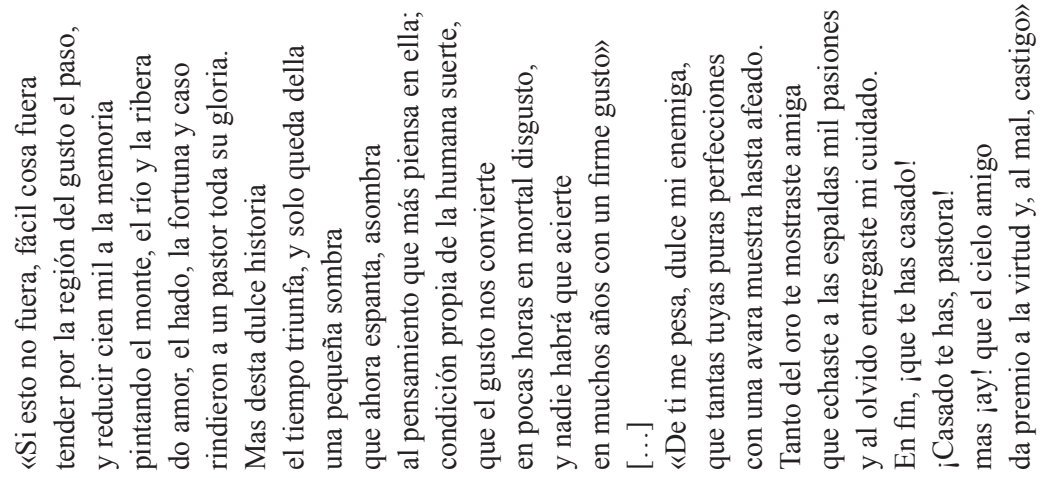


En el esquema que acabamos de reproducir, podemos ver un pormenorizado análisis rítmico de los fragmentos que Diego selecciona. Indicamos en cada caso la medida del verso y su rima, la distribución de los acentos que le dan forma, la vocal tónica, el tipo de acento ante el que nos encontramos (rítmico [R], extrarrítmico [E] o antirrítmico [A] (Domínguez Caparrós, 2000: 92-95)) $\mathrm{y}$, finalmente, la vocal tónica sobre la que recae.

Nos encontramos, en efecto, ante versos retóricos, prosaicos, que percibimos lejanos, cuando no algo humorísticos («En fin, ique te has casado!»); se trata, desde luego, de versos muy mirados y remirados por Diego con las peores intenciones, y, también, de versos del primer Cervantes. Pero dejemos todo eso a un lado. Lo que nos importa destacar es la pericia técnica que estos versos revelan, su calidad rítmica y prosódica. No están presentes aquí los mil y un defectos que siempre se le quieren afear a Cervantes; curiosamente, estas estrofas, lejos de demostrar la impericia técnica de Cervantes, con ser aquí todavía poeta bisoño, antes bien la niegan (ni acentos desubicados, ni supuestos versos hipermétricos, ni sinalefas violentas); y lo que ponen en duda son más bien todas esas teorías que ya hemos revisado y que quieren que Cervantes fuera un inigualable poeta en lo que al fondo, la invención y la estructuración de sus textos líricos se refiere. Examinados estos versos, hallamos únicamente seis acentos antirrítmicos (por tres extrarrítmicos y noventa y dos rítmicos); como es sabido, los acentos antirrítmicos son susceptibles de producir cacofonías; estilísticamente, sin embargo, pueden aprovecharse para propiciar determinados efectos expresivos. Examinemos los seis versos en los que aparece algún acento antirrítmico (subrayamos en todos los casos los acentos contiguos objeto de análisis):

1. Si esto no fuera, fácil cosa fuera

2. y reducir cien mil a la memoria

3. rindieron a un pastor toda su gloria.

4. al pensamiento que más piensa en ella

5. condición propia de la humana suerte,

6. da premio a la virtud y, al mal, castigo

En el segundo caso, nos encontramos ante un problema solo a medias: si bien cien, aisladamente, es una unidad tónica, lo cierto es que en cien mil el acento recae sobre mil, como si de una palabra aguda se tratase $\left({ }^{*}\right.$ cienmil): en definitiva, «y reducir cien mil a la memoria» es un ejemplo perfecto de endecasílabo sáfico acentuado en cuarta y sexta sílabas. En el tercer verso, la confluencia tónica entre pastor y toda se justifica por el aprovechamiento de la recurrencia fónica /tóR tó/, que en suma viene a subrayar la palabra toda, la más importante del verso, como demuestra el que se haga aparecer justamente en posición antirrítmica: en este caso, el acento en séptima consigue enfatizar el contenido semántico de la palabra presuntamente desubicada. «Al pensamiento que más piensa en ella», por su parte, se justifica de parecida manera: es ahora más la sílaba que coincide con el acento antirrítmico, lo cual evidentemente pretende, ahora también, subrayar el significado de la unidad desplazada. 
El primero y los dos últimos versos, por su parte, son, de nuevo, problemáticos solo a medias. «Si esto no fuera, fácil cosa fuera», "Condición propia de la humana suerte», y «da premio a la virtud y, al mal, castigo» no son versos cuya armonización plantee ningún problema, ya que, en suma, un acento antirrítmico en primera o tercera sílabas no comporta ni mucho los riesgos rítmicos que comporta su aparición en quinta o séptima sílabas, aunque este distingo no suele hacerse lo a menudo que debiera.

Además, si seguimos la información estadística ofrecida por Navarro Tomás acerca del uso que del endecasílabo hacen ciertos poetas, vemos que Cervantes se amolda especialmente al modo de Garcilaso (1982: 140). De hecho, en ningún otro poeta como en Cervantes y Garcilaso es tan frecuente el endecasílabo sáfico, más habitual en ellos que en otros autores del momento, tal que Quevedo o Herrera, como de nuevo ha demostrado Navarro Tomás. Tomando como base los versos copiados y elegidos por Diego, podemos ver que el endecasílabo más frecuente es el sáfico, al que siguen por este orden el heroico, el melódico y el enfático, orden que Navarro Tomás halla también en Garcilaso; si acudimos al número de ocasiones en que los acentos recaen sobre cada sílaba, la semejanza entre el endecasílabo garcilasiano y el cervantino se hace aún más patente ${ }^{7}$. Cervantes acentúa -siempre siguiendo este fragmento especialmente seleccionado por su torpeza- un 3\% de ocasiones en la primera sílaba (por un 4\% de Garcilaso), un 14\% en la segunda (por un $13,3 \%$ de Garcilaso), un $4 \%$ en la tercera (por un $4,5 \%$ de Garcilaso), un $17 \%$ en la cuarta (por un 15,6\% de Garcilaso), un $1 \%$ en la quinta (por un $0,5 \%$ de Garcilaso), un $14 \%$ en la sexta (por un $21 \%$ de Garcilaso), un $2 \%$ en la séptima (por un 1,1\% de Garcilaso), un $14 \%$ en la octava (por un $12,6 \%$ de Garcilaso), un $0 \%$ en la novena (por un $0,6 \%$ de Garcilaso) y un $24 \%$ en la décima (por un 26,2\% de Garcilaso). La única diferencia significativa, en la sílaba sexta, puede imputarse a la brevedad del fragmento.

Finaliza sus reparos Diego poniendo como ejemplo el terceto "Ármate de tus versos luego, y ponte / a punto de seguir ese vïaje / conmigo, y a la gran obra disponte» (Viaje, I, vv. 232-234), y escribe: «Son los defectos de este terceto de muestra los que más abundan y enfadan en la poesía cervantina. Desgracia del ritmo sintáctico, de la transición de un verso a otro, de las pausas que despedazan el verso por sitio contrario a las naturales coyunturas, como trinchador que no conoce su oficio y hace crujir los huesos del asado, salpicando de paso a los imprevistos comensales, repetición de palabras simples y compuestas en las rimas, elección, para fin de verso y rima, de vocablos incoloros y poco eufónicos, y colisión de acentos inmediatos» (Diego, 1948: 230).

De nuevo, como antes, cabe criticar el método seguido por Diego, consistente en juzgar a un poeta por sus peores momentos, deliberadamente

7. Tomamos como base los valores que Navarro Tomás ofrece acerca del endecasílabo de Garcilaso en el que pasa por ser su poema más logrado y plenamente clásico, la «Égloga III» (Navarro Tomás, 1982: 142). 
seleccionados y descontextualizados. Pero, en fin, ni con esas lleva Diego toda la razón. Es cierto que la rima del terceto es pobre (aunque si hubiera que impugnar a cada poeta que se ha servido de una rima de este tipo, se quedarían las bibliotecas vacías: si Cervantes rima aquí ponte con disponte, también rima Garcilaso hora con deshora -«Elegía II», vv. 43 y 45-), pero pocas acusaciones más están fundadas. Para empezar, prosódicamente no hay nada que decir de los versos: el primero es un perfecto endecasílabo enfático; y el segundo y el tercero, heroicos sin tacha. Es cierto que en el terceto se da un cierto desajuste entre entonación versal y entonación sintáctica, pero por la sencilla razón de que los versos primero y segundo acaban en sendos encabalgamientos, lo que no puede constituir ningún defecto. La esticomitia acabaría conduciendo al cansancio y al sonsonete, y más en un poema de tres mil doscientos noventa y ocho versos; se impone la utilización de ciertos recursos que hagan variable y flexible el ritmo del texto. Además, Diego parece orillar el contexto burlesco del poema, y el contenido admonitorio de estos versos, proferidos no se sabe si de burlas o de veras («a la gran obra disponte»), y en los que el contenido de los versos se ve subvertido, puesto en duda, por una forma cambiante y movediza.

Llama la atención la virulencia expresiva de Diego (toda esa metáfora del trinchador), virulencia injustificada y desde luego innecesaria. Creemos que viene a constituir una prueba más de la condescendencia con que se ha visto muchas veces a lo largo del siglo xx al Cervantes poeta, por influjo de las lecturas decimonónicas. No es desde luego remedio de posturas de este estilo saltar a la margen contraria, deduciendo apriorísticamente la calidad de los versos cervantinos y aplicándoles diversos moldes más o menos elaborados: el problema seguiría siendo el mismo, a saber, la falta de atención lectora, la falta de lectores con que se ha encontrado la poesía cervantina.

\section{CONCLUSIONES}

Hemos ido viendo que los desajustes métricos y estilísticos atribuidos a Cervantes las más de las veces no son tales; y cuando sí lo son, no merecen ni la insistencia ni la gravedad con que la crítica los ha tratado, dejándolos correr siempre en otros poetas del momento en quienes también se dan con igual o mayor frecuencia. En efecto, Cervantes es un poeta con ciertas caídas; un poeta que no está a la altura de los cuatro o cinco grandes poetas de su siglo, y no aceptar esto o querer demostrar su insuperable grandeza a través de otros méritos que lo son antes del crítico es leer con anteojeras. Porque, desde luego, Cervantes es formalmente uno de los poetas más variados de nuestra lengua; sus poemas mejores no desmerecen al lado de lo mejor de su siglo, y su obra en verso le erige como uno de los autores que con toda justicia sigue interesándonos cuatro siglos después de su muerte. Es hora de emprender un acercamiento verdaderamente sistemático a la poesía cervantina, 
superando la imagen decimonónica del Cervantes poeta en tanto que «ingenio lego» y evitando atajos como los que han llevado a formular explicaciones reduccionistas con las que dar carpetazo a los problemas que la lírica cervantina sigue planteándonos.

\section{BIBLIOGRAFÍA CITADA}

Alcalá Galán, Mercedes (2006). «Teoría de la poesía en Cervantes: poesía citada en la novela», Escritura desatada: poéticas de la representación en Cervantes. Alcalá de Henares: Centro de Estudios Cervantinos, pp. 179-196.

Alonso, Dámaso (2008). Poesía española. Ensayo de métodos y límites estilísticos (1950). Gredos: Madrid.

Ayala, Francisco (1971). «El túmulo» (1963), Los ensayos. Teoría y crítica literaria. Aguilar: Madrid.

Blecua, José Manuel (1970). «La poesía lírica de Cervantes» (1947), Sobre Poesía de la Edad de Oro. Gredos: Madrid, pp. 157-170.

Caballero Bonald, José Manuel (ed.) (2005), Miguel de Cervantes, Poesía. Barcelona: Seix Barral.

Cernuda, Luis (2006). «Cervantes, poeta» (1962), Obras completas II. Madrid: RBA-Instituto Cervantes, pp. 692-701.

Cervantes, Miguel de (1833-1839). El ingenioso hidalgo Don Quijote de La Mancha, Diego Clemencín (ed.). Madrid: Oficina de D. E. Aguado, Impresor de Cámara de S. M. y de su Real Casa, 6 vols.

Cervantes, Miguel de (1972). «La poesía de Miguel de Cervantes», en Adriana Lewis Galanes Poesía. Zaragoza: Ebro, pp. 15-38.

Cervantes, Miguel de (1974 y 1981). Poesías completas, Vicente Gaos (ed.). Madrid: Castalia, 2 vols.

Cervantes, Miguel de (1991). Viaje del Parnaso y Poesías sueltas, Elías L. Rivers (ed.). Madrid: Espasa, Clásicos Castellanos.

Cervantes, Miguel de (1995). La Galatea, Francisco López Estrada y María Teresa García Berdoy (eds.). Madrid: Cátedra.

Cervantes, Miguel de (2003). Teatro completo, Florencio Sevilla Arroyo y Antonio Rey Hazas (eds.). Madrid: Planeta.

Cervantes, Miguel de (2004). Don Quijote de La Mancha, Francisco Rico (dir.). Barcelona: Instituto Cervantes, Galaxia Gutemberg-Círculo de Lectores.

Cervantes, Miguel de (2005). Poesía, edición, selección e introducción de Alberto Blecua y notas de Antonio Pérez Lasheras. Zaragoza: Olifante.

Cervantes, Miguel de (2009). Tragedia de Numancia, estudio y edición crítica de Alfredo Baras Escolá. Zaragoza: Prensas Universitarias de Zaragoza.

Cuenca, Luis Alberto de (2005). «Cervantes, poeta», en Miguel de Cervantes, Poesía, edición, selección e introducción de Alberto Blecua y notas de Antonio Pérez Lasheras. Zaragoza: Olifante, pp. 211-212.

Diego, Gerardo (1948). «Cervantes y la poesía», Revista de Filología Española. XXXII, pp. 213-236.

Díez Echarri, Emiliano (1970). Teorías métricas del Siglo de Oro (1949). Madrid: CSIC.

Díez de Revenga, Francisco Javier (1995). «Cervantes poeta y su recepción por los poetas de nuestro siglo», BBMP. LXXI, p. 27.

Domínguez Caparrós, José (2000). Métrica española. Madrid: Síntesis. 
Domínguez Caparrós, José, (2002). Métrica de Cervantes. Alcalá de Henares: Centro de Estudios Cervantinos.

Gaos, Vicente (1974 y 1981). «Introducción», en Miguel de Cervantes, Poesías completas. Madrid: Castalia, pp. 7-46 y 7-28, 2 vols.

Gil de Biedma, Jaime (2010). Obras. Poesía y prosa. Barcelona: Galaxia Gutemberg.

Martínez Mata, Emilio (2008). Cervantes comenta el Quijote. Madrid: Cátedra.

Menéndez Pidal, Ramón (1940). Manual de gramática histórica española. Madrid: Espasa Calpe.

Menéndez Pelayo, Marcelino (1941). «Cervantes considerado como poeta» (1873), Edición Nacional de las Obras Completas de Menéndez Pelayo, vol. VI, Estudios y discursos de crítica Histórica y Literaria, I. Madrid: CSIC.

Micó, José María (2008). «Breve historia de la rima idéntica» (1984), Las razones del poeta. Forma poética e historia literaria de Dante a Borges. Madrid: Gredos, pp. 21-50.

Montero Reguera, José (2004). «"Poeta ilustre o al menos magnifico”. Reflexiones sobre el saber poético de Cervantes en El Quijote», Anales Cervantinos. xxxvi, pp. 37-56.

Montero Reguera, José (2005a). «A partir de dos sonetos del Quijote: estructura y ritmo del endecasílabo cervantino», Ínsula. 700-701, p. 35.

Montero Reguera, José (2011). «Heterodoxias poéticas cervantinas. (Prolegómenos a una edición crítica de la poesía de Miguel de Cervantes)», Ortodoxia y heterodoxia en Cervantes. Coloquio Internacional de la Asociación de Cervantistas. Alcalá de Henares: Centro de Estudios Cervantinos, pp. 245-271.

Montero Reguera, José, Romo Feito, Fernando, Cuiñas Gómez, Macarena, Collazo Gómez, Cristina y Dotras Bravo, Alexia (en prensa). «La edición de la poesía de Miguel de Cervantes». En: Emilio Martínez Mata y María Fernández Ferreiro (eds.), Comentarios a Cervantes. Actas del VIII Congreso Internacional de la Asociación de Cervantistas. Oviedo: Fundación María Cristina Masaveu Peterson.

Navarro Tomás, Tomás (1995). Métrica española (1956). Barcelona: Labor.

Navarro Tomás, Tomás (1982). Los poetas en sus versos. Desde Jorge Manrique a García Lorca. Barcelona: Ariel.

Rodríguez Marín, Francisco (1935). «Discurso preliminar» en Miguel de Cervantes, Viaje del Parnaso (1614). Madrid: Bermejo, pp. IX-LXXXIII.

Rodríguez Marín, Francisco (1947). Estudios cervantinos. Madrid: Atlas.

Rojas, Ricardo (1916). «De Cervantes considerado como poeta lírico», Poesías de Cervantes. Buenos Aires: Imprenta de Coni Hermanos, pp. VII-CII.

Rojas, Ricardo (ed.) (1916). Poesías de Cervantes. Buenos Aires: Imprenta de Coni Hermanos.

Ruiz Pérez, Pedro (2011). «Cervantes y la poesía», en Florencio Sevilla Arroyo (ed.), Museo iconográfico del Quijote. Guanajuato: Universidad de Guanajuato, pp. 157-204.

Solís de los Santos, José (2004). «Una edición crítica del soneto "Voto a Dios" de Cervantes», Philologia Hispalensis. vol. 18, 2, pp. 237-261.

Talens, Jenaro (1989). «Teoría y práctica poética en Cervantes», Homenaje al Profesor Antonio Gallego Morell. Granada: Universidad de Granada, vol. III, pp. 265-284.

Trabado Cabado, José Manuel (2000) Poética y pragmática del discurso lírico. El cancionero pastoril de La Galatea. Madrid: CSIC.

Valdés, Juan de (2008). Diálogo de la lengua (h. 1535), Rafael Lapesa (ed.), Tirant lo Blanch, Valencia.

Ynduráin, Francisco (1985). «La poesía de Cervantes: aproximaciones». Edad de Oro, IV, pp. 211-235.

Recibido: 17 de septiembre de 2012

Aceptado: 04 de octubre de 2013 


\title{
Resumen
}

Cervantes ha venido siendo considerado como un poeta mediocre y poco dotado técnicamente. En tres textos clásicos de gran influencia aún hoy, Ricardo Rojas, Francisco Rodríguez Marín y Gerardo Diego se refirieron al mal oído de Cervantes y a su torpeza como versificador, lo que ha llegado a ser un verdadero lugar común de la crítica cervantina. Recientes intentos de revaloración de la poesía de Cervantes han pasado por alto esta dura serie de reproches. Hoy examinados, muchos de los supuestos errores técnicos que tradicionalmente se han imputado a Cervantes no son ya tales las más de las veces. Es hora de revisar si verdaderamente fue Cervantes un poeta tan poco dotado técnicamente.

Palabras clave: Cervantes; poesía; métrica; estilística; defectos.

Title: Review of Cervantes' Poetry: Cervantes' Metric and Stylistic Defects.

\begin{abstract}
Cervantes has been considered as a technically clumsy poet. In three classic texts still very influential, Ricardo Rojas, Francisco Rodriguez Marin and Gerardo Diego referred to the poor versification of Cervantes and the metric limitations of his poetry: these accusations have become common places of criticism about Cervantes. Recent attempts to revalue the poetry of Cervantes have ignored those last series of statements. Today examined, many of the alleged technical defects that have traditionally been attributed to Cervantes did not deserve to be considered errors. It's time to check if Cervantes was a little technically gifted poet.
\end{abstract}

Key words: Cervantes; Poetry; Metrics; Style; Defects. 